\title{
Evaluation of papsmear in pregnancy
}

\author{
Samar Rudra, Ajita Mishra*, Akanksha Verma
}

Department of Obstetrics and Gynecology, Dr. D Y Patil University, Pune, Maharashtra, India

Received: 06 February 2021

Accepted: 06 May 2021

\section{*Correspondence:}

Dr. Ajita Mishra,

E-mail: drajita14@gmail.com

Copyright: ( $)$ the author(s), publisher and licensee Medip Academy. This is an open-access article distributed under the terms of the Creative Commons Attribution Non-Commercial License, which permits unrestricted non-commercial use, distribution, and reproduction in any medium, provided the original work is properly cited.

\section{ABSTRACT}

Background: Cervical cancer is common worldwide and ranks fourth among all malignancies for women. Cervical cytology (PAP smear) as a cancer screening method is most commonly used worldwide. Cervical cancer can be detected at an early stage by PAP smear which is a cost effective and easy to perform test which is also very safe in pregnant women, hence this study is taken up as an opportunistic time for cervical cancer screening to this accessible group of women during their antenatal period and to find detection rate of infectious diseases, precancerous and cancerous pathology of the cervix.

Methods: 500 pregnant women of age 21 years and above and between 16-24 weeks of gestation attending the antenatal OPD were included in the study. Scrapings were obtained from the ectocervix and sent for cytological evaluation. Findings were tabulated and statistically analysed.

Results: $7.2 \%$ of the patients in our study had cervical infection which included candidiasis and trichomonial infections. $0.4 \%$ of the patients had abnormal PAP report, and $88.2 \%$ had inflammatory smear implying higher risk of STD's and pregnancy related complications.

Conclusions: The cervical cytology is highly recommended for the routine screening in the antenatal care clinic specially for women who had no prior cervical cancer screening. Awareness on cervical cancer, preventive measures and screening methods need to be strengthened among pregnant women when they visit health care facilities and also in the community settings.

Keywords: Cervical cancer, Pap smear, Pregnancy, Screening

\section{INTRODUCTION}

Cervical cancer is common worldwide and ranks fourth among all malignancies for women. ${ }^{1}$ In developing countries, where health care resources are limited, cervical carcinoma is the second most common cancer among women and the third most common cause of mortality. ${ }^{2}$ Every year, more than 570,000 individuals are diagnosed with and 311,000 die from cervical cancer worldwide. The majority of these cases $(80 \%)$ are from developing countries. Current estimates indicate that every year 97,000 women are diagnosed with cervical cancer and 60,000 dies from the disease in India. ${ }^{3}$

This screening method has reduced the incidence and mortality of cancer cervix in the developed countries by
$70 \%$ over the past 50 years. ${ }^{4}$ Yet even today cervical cancer remains one of the leading causes of death for women in developing nations where the potential of a cervical cancer screening programs is underutilized. Needless to say, carcinoma cervix is one of the preventable cancers in females.

High-risk human papillomavirus (HPV) plays a central role in the development of cervical cancer. Out of more than 100 HPV strains, HPV 16, 18, 31, 45, 33, 35, 39, 51, 52, 56, 58, 66, 68 and 70 have been associated with cervical carcinoma. ${ }^{5}$ HPV prevalence among cervical cancer patients in India has varied from $87.28 \%$ to $93.8 \% .{ }^{6}$ Molecular studies have shown that HPV-16 and 18 are the two most common highly oncogenic types found in invasive cervical cancer, and account for $70 \%$ of 
cases of cervical cancer and precancerous cervical lesions. $^{7}$

Cervical cytology (PAP smear) as a screening method is most commonly used worldwide because it is a costeffective, easy to perform and effective method which can be implemented even in a rural setting. Cervical cytologic screening is one of modern medicine's greatest success stories. Countries with organized screening programs have been successful in reducing cervical cancer incidence by $79 \%$ and mortality by $70 \% .^{8}$ The specificity of cervical cytology is consistently high, ranging from $60 \%$ to $95 \%$. However, its sensitivity is lower and more variable ranging from $47 \%$ to $62 \% .{ }^{9}$ Poor sensitivity has been attributed to sampling or screening error or from error of interpretation.

Despite its enormous benefit and easy implementation advantages, Pap smear program has failed to take off in India due to various factors. The most common factor being the reluctance of women to come forward for the test even in socially advanced and aware women. All pregnant women generally come for the antenatal visits even in rural India. Antenatal counseling gives a great opportunity to make the women understand the benefits of the Pap test as a cancer cervix screening tool and motivate them to participate in the program. The antenatal period is one such opportunity to cover more women. The peak incidence of this disease is found in women in their third decade, which is also the time of their maximal childbearing period.

The incidence of abnormal cervical cytology in pregnancy is $0.72 \%$ to $1.67 \% .{ }^{10}$ Concomitantly there has been an increased frequency of detection of cervical intraepithelial neoplasia (CIN) in pregnancy due to cervical ectropion induced by pregnancy. However pregnant and non-pregnant women are at similar risk for CIN and cervical cancer. The incidence of CIN in pregnant and non-pregnant women does not have a significant difference $(0.82$ vs $0.46 \%)$. CIN occurs on an average in 1.3 per 1000 pregnancies (0.6-3.23/1000). Generally, the majority of pregnant women with CIN have CIN 1 or other evidence of HPV infection. CIN 3 is comparatively less common among pregnant females. pregnancy does not seem to alter the biological behaviour of tumour when compared with the nonpregnant state. ${ }^{10}$

Besides the detection of precancerous and cancerous lesions, Pap smear during pregnancy can also reveal other information like infective or inflammatory changes giving an opportunity to detect any vaginal infection, appropriate treatment of which give a better perinatal outcome.

Hence, this study is taken up as an opportunistic time for cervical cancer screening to find the detection rate of precancerous and cancerous pathology of the cervix when pregnant women come for their mandatory antenatal check-up.

\section{METHODS}

This prospective cohort observational study was done at a tertiary care teaching hospital over a period of two years among 500 pregnant patients aged 21 years and above and between 16-24 weeks of gestation attending the antenatal OPD who were included for the study. Women with a history of threatened abortion in present pregnancy, history of sexual intercourse, vaginal douching, or vaginal medication in the past 48 hours were excluded from the study.

Recruited patients were assessed about their knowledge of Pap test and Carcinoma cervix which were noted down on the data sheet. A detailed history taking, general and systemic examination including an obstetric examination were performed.

Thereafter the patients were explained about the procedure of the Pap smear. Pap smear were taken from each patents and sent to cytology lab for evaluation.

This opportunity was also utilized to find any cervical or vaginal infection or inflammation.

Pregnant women having cervical cytology were advised that vaginal spotting may occur after the procedure and that it poses no risk to pregnancy and is self-limiting.

The reporting of the slides was done as per the Bethesda classification. All data was entered in the EXEL sheet, tabulated, and analyzed using SPSS version 22.0. Quantitative data were summarized using mean and Standard Deviation. Quantitative data were summarized using proportions.

Institutional Ethical Committee clearance was obtained before the commencement of the study.

\section{RESULTS}

The mean age of the participants was 25.46 years $(\mathrm{Sd}: 3.25)$ with a median age of 25 years and age range of 21 to 37 years.

Table 1: Age distribution analysis.

\begin{tabular}{|lll|}
\hline Age (years) & No. of subjects & $\%$ \\
\hline $\mathbf{2 1 - 2 5}$ & 290 & 58 \\
\hline $\mathbf{2 6 - 3 0}$ & 180 & 36 \\
\hline $\mathbf{3 0}$ & 30 & 6 \\
\hline Total & 500 & 100 \\
\hline
\end{tabular}

A total $40.6 \%$ of patients were not educated, $44.6 \%$ had studied till secondary level, and only $14.8 \%$ of patients were graduates. Majority of the patients belonged to lower SE class at $45.8 \%$, Patients belonging to middle SE class were $45.8 \%$ and $19.6 \%$ belonged to upper SE class. 
Table 2: Demographic data on educational status and socio-economic status.

\begin{tabular}{|c|c|c|c|}
\hline & & $\begin{array}{l}\text { No. of } \\
\text { subjects }\end{array}$ & $\%$ \\
\hline \multirow{4}{*}{ Literacy } & Illiterate & 203 & 40.6 \\
\hline & Secondary & 223 & 44.6 \\
\hline & Graduate & 74 & 14.8 \\
\hline & Total & 500 & 100 \\
\hline \multirow{4}{*}{$\begin{array}{l}\text { Socioeconomic } \\
\text { class }\end{array}$} & $\begin{array}{l}\text { Lower } \\
\text { SE* class }\end{array}$ & 229 & 45.8 \\
\hline & $\begin{array}{l}\text { Middle SE } \\
\text { class }\end{array}$ & 173 & 34.6 \\
\hline & $\begin{array}{l}\text { Upper SE } \\
\text { class }\end{array}$ & 98 & 19.6 \\
\hline & Total & 500 & 100 \\
\hline
\end{tabular}

Table 3: Awareness of ca cervix and pap smear in pregnant women.

\begin{tabular}{|llll|}
\hline $\begin{array}{l}\text { Subject } \\
\text { Awareness }\end{array}$ & Yes & No & Total \\
\hline Pap smear & $31(6.2 \%)$ & $469(93.8 \%)$ & $500(100 \%)$ \\
\hline Ca Cervix & $80(16 \%)$ & $420(84 \%)$ & $500(100 \%)$ \\
\hline
\end{tabular}

$6.2 \%$ of the subjects were aware about Pap smear compared to $16 \%$ who were aware about carcinoma cervix. Majority of our patients were ignorant about both carcinoma cervix as well as the screening method for it at $84 \%$ and $93.8 \%$ respectively.
Table 4: Cervical examination findings.

\begin{tabular}{|lll|}
\hline $\begin{array}{l}\text { Cervical Per speculum } \\
\text { findings }\end{array}$ & No. of subjects & $\%$ \\
\hline Normal & 444 & 88.8 \\
\hline Infection & 36 & 7.2 \\
\hline Cervical lesion & 20 & 4 \\
\hline Total & 500 & 100 \\
\hline
\end{tabular}

Per speculum examination revealed infection in $7.2 \%$ of the patients, out of which $3 \%$ patients had candida infection. $4 \%$ of the patients had presence of cervical lesion and all of them had erosion of cervix and $88.8 \%$ had a normal finding.

Table 5: Pap smear findings.

\begin{tabular}{|lll|}
\hline Pap Smear findings & No. of subjects & $\%$ \\
\hline Normal & 56 & 11.2 \\
\hline Inflammatory Smear & 442 & 88.4 \\
\hline ASCUS & 2 & 0.4 \\
\hline Total & 500 & 100 \\
\hline
\end{tabular}

$88.4 \%$ of the participants had inflammatory smear, $11.2 \%$ had normal smear and $0.4 \%$ had ASCUS. Out of those having inflammatory smear $3 \%$ of the patients had candida infection and rest having nonspecific infection and inflammation.

Table 6: Educational status Vs Pap smear analysis.

\begin{tabular}{|lllllllll|}
\hline Education & $\begin{array}{l}\text { Normal } \\
\text { Smear }\end{array}$ & $\%$ & Inflammatory Smear & $\%$ & ASCUS & $\%$ & Total & $\%$ \\
\hline Illiterate & 17 & 3.4 & 185 & 37 & 1 & 0.2 & 203 & 40.6 \\
\hline Secondary & 33 & 6.6 & 189 & 37.8 & 1 & 0.2 & 223 & 44.6 \\
\hline Graduate & 6 & 1.2 & 68 & 13.6 & 0 & 0 & 74 & 14.8 \\
\hline Total & 56 & 11.2 & 442 & 88.4 & 2 & 0.4 & 500 & 100 \\
\hline
\end{tabular}

Table 7: Correlation of Clinical Cervical findings and Pap smear results.

\begin{tabular}{|lllllllll|}
\hline $\begin{array}{l}\text { Cervical clinical } \\
\text { findings }\end{array}$ & $\begin{array}{l}\text { Normal } \\
\text { Smear }\end{array}$ & $\%$ & Inflammatory Smear & $\%$ & ASCUS & $\%$ & Total & $\%$ \\
\hline Normal & 50 & 10 & 320 & 64 & 1 & 0.2 & 371 & 74.2 \\
\hline Infection & 4 & 0.8 & 104 & 20.8 & 1 & 0.2 & 109 & 21.8 \\
\hline Cervical lesion & 2 & 0.4 & 18 & 3.6 & 0 & 0 & 20 & 4 \\
\hline Total & 56 & 11.2 & 442 & 88.4 & 2 & 0.4 & 500 & 100 \\
\hline
\end{tabular}

Of 2 patients with ASCUS, one was illiterate and another had secondary education. Of those with inflammatory smear, minimum number of cases i.e. $3.6 \%$ were from graduate group, $37.8 \%$ had secondary education, $37 \%$ were not educated. Of those with normal smear $1.2 \%$ were graduates, $6.6 \%$ were educated till secondary level, $3.4 \%$ were not educated. Majority of our patients had inflammatory smear (88.4\%) from which $64 \%$ had normal cervix clinically, $20.8 \%$ had evidence of infection or inflammation and only $3.6 \%$ had cervical lesion mainly erosion cervix. Only 2 cases were found to have ASCUS, one with normal cervix clinically and other one had evidence of infection. Only $11.2 \%$ cases had normal smear from which $10 \%$ had normal cervix, $0.8 \%$ had evidence of infection and $0.4 \%$ had cervical lesion clinically. 


\section{DISCUSSION}

In the present study, $58 \%$ of pregnant women screened were in the age group of 21-25 years and $6 \%$ were above 30 years. Radha Bai Prabhu T et al in their study reported about $52 \%$ were in the age group of $21-25$ years which is similar to our study. ${ }^{11}$ Manikkam B et al had $33.5 \%$ in the range of 20-25 years in their study. ${ }^{12}$

Regarding the education of pregnant women, the present study had $40.6 \%$ illiterates, $44.6 \%$ studied up to secondary level, and only $14.8 \%$ were graduates. The level of education will have an impact on the knowledge about cervical cancer and could be a pre-requisite for improving awareness about cervical cancer screening among antenatal women. In various other studies taken the literacy rate was far better than our study as in this study majority of patients were from rural background. Manikkam et al reported that the majority $(65.5 \%)$ had attended college/University. ${ }^{12}$ Khaengkhor $\mathrm{P}$ et al reported that the majority had obtained higher education. $^{13}$

In the present study, the majority of the patients belonged to the middle socio-economic class at $34.6 \%$, the lower socio-economic class was $45.8 \%$ and $19.6 \%$ were upper socio-economic class. This shows that close to half of the pregnant women were from the lower socio-economic class. Reporting of socio-economic status was not consistent in the previous studies and hence we could not compare with other Indian studies. Regarding awareness about cervical cancer, $16 \%$ of pregnant women in the present study had heard about cervical cancer whereas $84 \%$ were unaware of cervical cancer as majority of patients in our study group had low literacy. In contrast to the study by Manikkam et al where $80 \%$ had knowledge regarding screening for cervical cancer (heard about PAP test). ${ }^{12}$ The present study reported that $6.2 \%$ had heard about PAP smear test. Studies by Dinc et al in Turkey reported $60.7 \%$ of the pregnant women had heard about the PAP test. ${ }^{14}$

Cervical examination in the present study revealed infection in $7.2 \%$ of the patients which included bacterial vaginosis, candidiasis, and trichomonal infections. $4 \%$ had the presence of cervical lesions, all of which were cervical ectropion and $88.8 \%$ had a normal per speculum examination. Infective vaginal discharge in pregnancy increases due to alterations in vaginal $\mathrm{pH}$ under hormonal influences. ${ }^{12}$ Priya et al reported that $89 \%$ of the antenatal mothers had a healthy cervix and $10 \%$ had cervical erosion and $1 \%$ had a growth on the cervix. ${ }^{10}$ Mohindroo $\mathrm{N}$ et al reported that $8.8 \%$ of the pregnant women had an unhealthy cervix during speculum examination. ${ }^{15}$

\section{Pap smear}

In our study only $0.4 \%$ of patients had ASCUS, $88.4 \%$ had an inflammatory smear and $11.2 \%$ of patients had a normal smear.
Of inflammatory smears, the majority of the cases had mild to moderate degrees of inflammation. Out of the smears with moderate inflammation 12 patients had candida infection, and the rest of the inflammatory smear was found to be non-specific. In our study, we have found more percentage of inflammatory smears.

An inflammatory component is commonly seen on PAP smears from pregnant women. ${ }^{12}$ A study by Bedrossian et al evaluated the significance of inflammatory PAP smear and attributed it to high-risk pregnancy and found that these patients had a higher risk for sexually transmitted diseases and pregnancy-related complications, recommending a closer observation of patients with inflammatory smear in pregnancy. ${ }^{12}$

Table 8: PAP smear findings of different studies and our study is tabulated below.

\begin{tabular}{|llll|}
\hline $\begin{array}{l}\text { Name of } \\
\text { study }\end{array}$ & Normal & Inflammatory & Abnormal \\
\hline $\begin{array}{l}\text { Manikkam et } \\
\text { al }^{\mathbf{1 2}}\end{array}$ & $40.5 \%$ & $57 \%$ & $0.5 \%$ \\
\hline Priya S et al $^{\mathbf{1 0}}$ & $66 \%$ & $26 \%$ & $1 \%$ \\
\hline $\begin{array}{l}\text { Mohindroo N } \\
\text { et al }^{\mathbf{1 5}}\end{array}$ & $46.1 \%$ & 31.18 & $22.72 \%$ \\
\hline $\begin{array}{l}\text { Khaengkhor } \\
\text { P et al }\end{array}$ & $59.4 \%$ & $33.6 \%$ & $7 \%$ \\
\hline Our study & $11.2 \%$ & $88.4 \%$ & $0.4 \%$ \\
\hline
\end{tabular}

The finding of abnormal smear $(0.4 \%)$ in our study is similar to the study by Manikkam et al $(0.5 \%)$ and Priya $\mathrm{S}$ et al $(1 \%) .{ }^{12,10}$ However, Mohindroo $\mathrm{N}$ et al found a high percentage of patients with abnormal smear $(22.7 \%) .{ }^{15}$ In their study, $22.72 \%$ had an abnormal smear as their study classified the smears under normal, inflammatory, bacterial vaginosis, trichomonas vaginalis and monilial infections. Abnormal smear accounted for bacterial vaginosis, trichomonas vaginalis and monilial infection which was $22.72 \%$.

In the present study, of two patients with ASCUS, one was illiterate and another had secondary education. Of those with inflammatory smears, $13.6 \%$ were graduates, $37.8 \%$ had secondary education and $37 \%$ were illiterates. Khaengkhor $\mathrm{P}$ et al reported $7 \%$ of patients with abnormal Pap smear findings; of them, $80 \%$ had secondary school education and $20 \%$ had primary school education and none were illiterate. ${ }^{13}$

In the present study, of 2 patients with ASCUS, cervical per speculum findings were reported normal in one patient and one had an infection. Of patients with inflammatory smear, $20.8 \%$ had an infection, $3.6 \%$ had cervical lesions all of which were ectropion and $64 \%$ had normal cervical finding on per speculum. Of patients with normal smear, $0.8 \%$ had an infection, $0.4 \%$ had cervical lesion which was ectropion and $10 \%$ had normal per speculum examination. In the study by Mohindroo et al, the authors reported that the correlation of abnormal 
smears to an unhealthy cervix was significant $(\mathrm{p}=0.0007) .{ }^{15}$ An unhealthy cervix per speculum indicates cervical pathology and is independently associated with an abnormal Pap smear. In their study, in those with an unhealthy cervix, 91.2\% had an abnormal Pap smear, whereas, in those with healthy cervix on per speculum examination, $47.2 \%$ had an abnormal smear.

\section{CONCLUSION}

Our study is an attempt to determine the importance of opportunistic screening for cervical cancer to this accessible group of women during their antenatal period to detect precancerous and cancerous pathology of the cervix, to detect vaginal infections, allowing us to give appropriate treatment and preventing pregnancy complications like preterm labour and premature rupture of membranes. If we can do Pap smear in all pregnant women during their antenatal visit then probably a large population will be covered for at least once for cervical cancer screening. India has a high burden of neoplastic cervical disease and efforts must be made to decrease the morbidity and mortality from this preventable disease.

Funding: No funding sources

Conflict of interest: None declared

Ethical approval: The study was approved by the Institutional Ethics Committee

\section{REFERENCES}

1. Globacan. Cervical cancer: estimated incidence mortality and prevalence worldwide in 2012. 2012: Available at: http://globocan.iarc.fr/old/FactSheets/cancers/ cervix-new.asp. Accessed on $1^{\text {st }}$ January 2021.

2. Neerja B, Daisuke A, Nand SD, Rengaswamy S. Cancer of the cervix uteri $[\mathrm{J}]$. Int J Gynaecol Obstet. 2018;143:22-36.

3. Ferlay J, Soerjomataram I, Ervik M, Dikshit R, Eser S, Mathers C, et al. GLOBOCAN 2012 v1.0, Cancer Incidence and Mortality Worldwide: IARC Cancer Base No. 11. Lyon, France. 2013: Available at: http://globocan.iarc.fr. Accessed on $1^{\text {st }}$ January 2021.

4. Mahboobeh S, Solomon D, Philip E. Castle, Cervical Cancer Prevention-Cervical Screening: Science in Evolution,Obstetrics and Gynecol Clinics of North America. 2007;34(4):739-60.

5. Bonnez W, Reichman RC. Papillomaviruses. In G. L. Mandell, J. E. Bennett, and R. Dolin (ed.),
Mandell, Douglas, and Bennett's principles and practice of infectious diseases, 5th ed. Churchill Livingston, Philadelphia. 2000:1630-40.

6. Senapati R, Nayak B, Kar S K, Bhagirathi D. HPV Genotypes distribution in Indian women with and without cervical carcinoma: Implication for HPV vaccination program in Odisha, Eastern India. BMC Infect Dis. 2017; 17:30.

7. WHO 2019 guidelines. Available at: https://www.who.int/news-room/fact-

sheets/detail/human-papillomavirus-(hpv)-andcervical-cancer. Accessed on $1^{\text {st }}$ January 2021.

8. Ries L, Eisner MP, Kosary CL, Hankey BF, Miller BA, Clegg L, Mariotto A, Feuer EJ, Edwards BK. SEER Cancer Statistics Review. 1975-2002. Bethesda, MD: National Cancer Institute; 2004.

9. Nanda K, McCrory DC, Myers ER, LA Bastian, V Hasselblad, JD Hickey, DB Matchar Accuracy of the Papanicolaou test in screening for and follow-up of cervical cytologic abnormalities: a systematic review. Ann Intern Med. 2000;132:810-9.

10. Priya SS, Shankar R. PAP smear in pregnancy: a hospital based study. Int J Reprod Contracept ObstetGynecol. 2018;7:4924-8.

11. RadhaBaiPrabhu T, Velayudham D, Nethaji S, Singhal H, venkatachalam R. Opportunistic Cervical Cancer Screening in Pregnancy. International Journal of Medical Research and Health Sci. 2016;5:2-278.

12. Manikkam B. Screening for cervical cancer during pregnancy. Int $\mathbf{J}$ Community Med Public Health 2016;3:2493-8.

13. Khaengkhor $\mathrm{P}$, Mairaing $\mathrm{K}$, Suwannarurk K, Thaweekul Y, Poomtavorn Y, Pattaraarchachai J, et al. Prevalence of abnormal cervical cytology by liquid based cytology in the antenatal care clinic, Thammasat University Hospital. J Med Assoc Thai. 2011;94:152-8.

14. Dinc A. Pap Smear Screening Results for Turkish Pregnant Women. Asian Pacific J Cancer Prevention. 2012;13(11):5835-8.

15. Mohindroo N, Sharma A, Minhas S, Pathania K. Prevalence and associated risk factors of abnormal pap smear in pregnant women.Int $\mathbf{J}$ Reprod Contracept Obstet Gynecol. 2019;8:4980-4.

Cite this article as: Rudra S, Mishra A, Verma A. Evaluation of papsmear in pregnancy. Int J Reprod Contracept Obstet Gynecol 2021;10:2374-8. 